\title{
Time, Waste, and the City: The Rise of the Environmental Industry
}

\author{
Key MacFarlane (10) \\ History of Consciousness Department, University of California Santa Cruz, Santa Cruz, CA, USA; \\ kmacfarl@ucsc.edu
}

\begin{abstract}
In many US cities, especially those in the Rust Belt, the environmental goods and services (EGS) industry has played a significant role in restructuring local economies to promote new, flexible, and "creative" forms of service-based labour. And yet much of the environmental work conducted in these cities has been directed at an industrial past, cleaning up the waste left over from long-departed manufacturing sectors. Returning to David Harvey's earlier work on the urban process, this paper develops a theory of waste switching that situates EGS within a larger renegotiation of space and time across city landscapes. This theory is fleshed out in case studies of the EGS industry in Baltimore, Pittsburgh, and Milwaukee, where new cycles of accumulation have been built on refuse, toxins, and dead labour. These "toxi-cities" and their cleanup challenge traditional conceptions of urbanisation as spatially — but also temporally - bounded.
\end{abstract}

Keywords: urban, environment, waste, time, capital, economy

\section{Gravedigging}

Recently Jason Moore (2015) has put an ecological spin on the old Marxist notion that capitalist society creates its own gravediggers. ${ }^{1}$ For Moore, capitalism relies on a strategy of "Cheap Nature" that, through the law of value, transforms landscapes into extractable sources of cheap labour, food, energy, and raw materials. But the end of Cheap Nature is in sight, Moore says. Capitalism has devastated the planet, leading to widespread environmental catastrophe and economic depression. This has become especially apparent since the 1970s, as the opportunities for appropriating cheap natures have decidedly dwindled. The accumulation of capital from unpaid work is suddenly challenged by the "accumulation of waste and toxification" (Moore 2015:308). Moore argues that new methods of financialisation and a shift in attention to the sphere of reproduction have helped postpone the ultimate collapse of capitalism into the future. But as an inherently "wasteful system" capitalism's days are surely numbered (Moore 2014). The onset of terminal crisis is "unpredictable but inevitable" (Moore 2015:1).

The environmental goods and services (EGS) industry plants a seed of doubt in this thesis. Since it emerged on a global level during the 1960s and 1970s, EGS has made a living off the toxic wastelands that Moore and others see as fatal to capital accumulation (Sinclair-Desgagné 2008). In the US, this industry has been especially profitable. With the exclusion of a period from 1996 to 1999, EGS growth has remained higher than that of US gross domestic product (GDP) (EBJ 2015). Today, the US industry produces around $\$ 360$ billion in total revenues 
each year and accounts for nearly $40 \%$ of the global market for environmental services (US International Trade Commission 2013). In addition to direct profitability, environmental services have also played a major role in the cleanup and "post-industrial" restructuring of urban economies over the past few decades, particularly in Rust Belt cities (Hathaway 2012). The remediation and reclamation of old manufacturing sites and military testing facilities has reopened these spaces, both within and beyond the city, to new cycles of investment and value extraction, either in the form of tourism or further development (see, e.g., Dillon 2014). In places like Baltimore, Milwaukee, and Pittsburgh, the cleanup of urban landscapes has been part of a larger set of initiatives for building a "creative city" that provides "innovative solutions to urban problems" (Landry 2008:xvi). Seen in this context, the EGS industry shows how the greening of urban space is more than a reaction to environmental disaster; it is also a direct reflection of and attempt to reverse economic decline. If capitalist society creates its own gravediggers, it has created its own graverobbers as well. The toxic refuse of the past, once pronounced dead and buried, is now dug up, reanimated, and turned into profit. Environmental destruction, it turns out, can make for good business (see also Schoenberger 2015).

Rising from the soils of capitalist ruin, the EGS sector provides an empirical example of what David Harvey (2018:93) has recently reminded us: that crises do not necessarily spell the end of capitalism but "set the stage for its renewal". Fully grasping this point, for Harvey, requires digging up a faint, but vital, current in Marx's value theory. This is the concept of what Harvey calls "antivalue", introduced by Marx in passing at the end of the first chapter of Capital. Unlike Moore's (2015:276) "negative value", which amasses in earnest only after the "paradigm moment" of climate change, anti-value has been imbricated with accumulation from the start (and in ways that are not merely "latent"). In Harvey's reading of Marx, value only exists in dialectical relation to its potential loss - to the threat of devaluation and uselessness. Anti-value is thus depicted as a kind of ghost that "hovers over ... [capital] as it circulates", always threatening to interrupt the latter's continuity (Harvey 2018:72). And yet this is also a productive relationship: when overcome_-"redeemed as it were" (Harvey 2018:74) -anti-value can re-establish the geographic and temporal limits of extraction and exchange.

To the extent they are rendered "useless", contaminated landscapes, discarded commodities, and "disposable" individuals are real world embodiments of antivalue (cf. Katz 2011; Wright 2006). Vinay Gidwani (2008:19) has developed this point in his work on waste-picking economies in India. "Waste", he argues, "is the specter that haunts value" - marking certain things, places, and lives as surplus and literal refuse. But this haunting can also be reversed. In redeeming sites of waste, making them productive and profitable once again, the EGS industry in India and elsewhere reveals an important aspect of anti-value, one that is implicit but not fully fleshed out in Harvey's account. This is its temporality. In toxic wastelands, anti-value is located "in the past" - as the bygone leftovers of previous cycles of accumulation. In the US, such anachronism bares itself most clearly in abandoned urban manufacturing sites, where rusting equipment and arsenic- 
laced soils leave traces of the past on their surroundings, and within the bodies of those living nearby. Isn't the goal of EGS work to re-collect and recycle these pasts, to bring them back into the productive spaces of the capitalist present?

To pose such a question is to consider the environmental sector, particularly remediation services, as a potential challenge to the spatio-temporal boundedness of urban space. The geographical study of urbanisation has long been dominated by work examining traditional agglomerations and market exchange relations (Schoenberger and Walker 2017). Focusing solely on these structures, on how cities appear today, overlooks the actual social relations that have made urbanisation possible, some of which are non-urban and non-present (cf. Brenner and Schmid 2017). What's needed instead is to examine the "historical-geographical roots" of contemporary markets (Schoenberger and Walker 2017:938). The rise of environmental services suggests that these roots run through contaminated soil. But how deep do they go? How much of today's urban growth is built on past cycles of toxic production?

This paper explores the extent to which "creative cities" are constructed on and through timeworn wastelands of anti-value-what I call toxi-cities. On the one hand, toxi-cities include the actual toxic practices of past industrial cycles and military activities, which provide new sources of profit for urban economies and often act as a kind of temporal hinterlands for value extraction. This demonstrates how the city achieves a "creative" economy not just through the circulation of ideas but "because it creates problems to be solved", including legacies of toxicity (Schoenberger and Walker 2017:947). Sometimes, as in Flint, Michigan, these legacies have literally manufactured a toxic city (cf. Benz 2017). Building on the work of Gidwani and Reddy (2011), toxi-cities also refer to waste in a larger sense, to the often-racialised bodies and spaces excluded from, threatened, and made obsolete by urban revitalisation. Though still a relatively small industry in the global sense, with a $\$ 1.2$ trillion market (EBJ 2017), the environmental sector provides insights into how such toxi-cities are managed and remediated in urban space, and how this remediation relies on a constant renegotiation with the past, of digging up what had been labelled as waste and left for dead.

The analysis of toxi-cities contributes to an emerging scholarship within geography on waste (see, e.g., Gidwani 2016; Gidwani and Reddy 2011; Katz 2011; Krupar 2011; Lindner and Meissner 2016). Some of this literature has considered the ways waste cleanup can conserve the past within the present, especially in urban space. In her study of brownfield redevelopment in San Francisco, for instance, Lindsey Dillon (2014:1207) argues that the very idea of the "post-industrial" is challenged by the work of remediation, since industrialisation remains, as it were, in the toxic debris left behind. Thus, if the urban can no longer be conceived as spatially fixed (Brenner and Schmid 2017), neither is it temporally bounded.

While Dillon and others have opened an important historical dimension in the remediation of urban waste, this economic sector itself remains underhistoricised, as has the global EGS industry more generally. Seeking to remedy this, I propose a theory of waste switching that situates the rise of the US EGS industry within a larger socioeconomic restructuring that occurred throughout the Rust Belt, 
particularly in the 1980s and 1990s, as cities felt the pressures of globalisation and sought to replace a decimated manufacturing sector (Hathaway 2012; Hobor 2013). Framing EGS in this way historicises the management of toxi-cities in terms of what Noel Castree (2008) has called "environmental fix". But more than just a strategy for deferring crisis into the future, the "fix" of environmental remediation also seeks to recover the "dead labor" (Marx 1990:342) left over from the trauma of economic decline and ecological devastation. In developing this point in the section below, I return to Harvey's earlier work on the urban process, placing environmental services within the three circuits of capital he outlines there. This theory is then fleshed out in case studies of the EGS industry in Baltimore, Pittsburgh, and Milwaukee.

What this paper offers is an inverted reading of the rise of the EGS industry, one that is less about warding off a toxic future and more about warding off political and economic crisis through the re-collection of a toxic past. Ultimately, EGS is found to fall short in its ability to revitalise capital accumulation over the long run. Yet it remains an important reminder of how capitalism's "inevitable destruction" can be postponed or, perhaps, prolonged. Will other strategies of capitalist re-collection emerge in the future or is collapse finally imminent? Rather than wait around to find out, the paper's conclusion explores some of the subterranean spaces where more radical forms of re-collection can and do occur-seeking to transform the world, waste and all.

\section{Theory of Waste Switching Historical Delay}

Capitalism has always been a "wasteful system" (Moore 2014) causing alterations in environmental quality and key global climate variables since the late $18^{\text {th }}$ century (Crutzen 2002) and probably earlier. And yet the business of cleaning it up is a much more recent phenomenon. According to most scholars, the modern EGS industry did not fully emerge in the US and elsewhere until the 1960s, growing rapidly in the 1970s and 1980s (Hathaway 2012). How are we to account for this historical delay?

Of course, many environmental services came into existence far earlier. Waste disposal practices, as archaeologists have shown, are likely as old as civilisation itself. In the US, most large cities had municipal programs in place for addressing water supply, garbage collection, and sewage systems by the end of the $19^{\text {th }}$ century (Schoenberger and Walker 2017; Sinclair-Desgagné 2008). But these services make up only a portion of the modern EGS industry, a sector famously difficult to measure and define (Boyd and Banzhaf 2007; Fisher et al. 2009). For the OECD (1999a:9), EGS consists of activities that "produce goods and services to measure, prevent, limit, minimise or correct environmental damage to water, air and soil, as well as problems related to waste, noise and eco-systems". These goods and services are divided into three groups: resource management, cleaner technologies and products, and pollution management. The latter includes air pollution control, wastewater management, solid waste management, remediation and 
clean-up of soil and water, noise and vibration abatement, as well as monitoring, analysis, and assessment.

Within the amalgam of EGS labour there are different temporalities at play. Activities like solid waste management might be said to remove and repress the past, removing unwanted refuse from the visible urban landscape, burying it beneath the city or in landfills - or else burning it altogether. Services related to environmental remediation, as I show in the next section, are more therapeutic. They work through and re-mediate the toxic remains of capitalist production, making these productive of value once again, turning environmental "bads" back into commoditised "goods". It is the latter group of services that emerged more recently, beginning in the 1970s before taking off in the late 1980s and 1990s (Sutherson et al. 2017). Understanding the temporality of environmental remediation - as always also capital re-mediation - is key to grasping the historical-geographic roots of this market along with modern EGS more generally as a profit-generating industry. And yet this is something that most accounts of the environmental sector fail to do.

In environmental policy fields, the EGS sector is usually framed as the progressive outcome of social movements and specific acts of legislation. Many studies stress the role played by public concern and grassroots organising in generating institutional change and providing the impetus for new industries from for-profit recycling (Lounsbury et al. 2003) to wind energy (Sine and Lee 2009). A recurring motif is how, since the 1960s, the "heroic effort" of the US environmental movement has led to shifts in public values and the gradual adoption of regulations at national and local levels (Kraft 2000; see also Percival et al. 2015). Such legislation is often held as the "most important factor" (Vikhlyaev 2004:36) or "main driver of demand" (Sinclair-Desgagné 2008:3) for environmental goods and services.

There is of course much truth to this. As federal governments began introducing comprehensive land restoration policies, these required regulatory compliance. Particularly important in the US was the National Environmental Policy Act (NEPA) of 1970, which directed federal budgets towards environmental assessment and research. As the remediation industry emerged at the end of the decade, its main activities included hazardous waste handling, transport, and disposal. It was not until the 1980s that remediation was consistently implemented for sites that had been contaminated in the past. Such cleanup was made legally obligatory with the enactment of the Comprehensive Environmental Restoration, Compensation, and Liability Act (CERCLA or "Superfund") in 1980 and the Superfund Amendments and Reauthorization Act (SARA) in 1986. Other important market drivers included the introduction of underground storage tank (UST) regulations and the 1984 Hazardous and Solid Waste Amendments to the Resource Conservation and Recovery Act (RCRA) (see Ellis and Hadley 2009; Sutherson et al. 2017).

Policy-based accounts of EGS formation are tempting. They provide an explanation for the historical delay of the industry: that it emerged at a certain threshold of public awareness and legal development. It is in this way that environmental services can be held up as progressive, signifying an advancement over-and 
a willingness to clean up and move on from - "older" and "cruder" forms of capitalist production.

\section{Waste Switching}

But what if the environmental sector is not an annulment of older cycles of production but, on a larger timescale, a continuation of - if not a return to - its value making potential? Exploring this question requires a temporally robust view of Harvey's (2018) anti-value as it relates to the reclamation of environmental toxicity. Returning to Harvey's (1989:62) earlier work on the urban process is helpful here, particularly to his schema of the primary, secondary, and tertiary circuits of capital, which enabled him to consider production and consumption over multiple time periods. How does anti-value or waste operate within this framework - along with its remediation ${ }^{2}$

It is important to see how waste takes shape in the primary circuit of capital, that of commodity production. Rather than an inefficiency or avoidable "externality", waste is immanent to the production process itself and key to the creation of surplus value. At this point, waste is supplied by exploited workers who, in being paid below the value of their labour, serve as the substrate of anti-value from which surplus value is extracted. Such anti-value is not initially "latent", in Moore's (2015:276) sense, because it appears objectively within immiserated bodies. But it does become concealed: anti-value is displaced at the moment of valorisation. On the one hand, waste is displaced onto the commodities themselves in the form of future decay and actual toxicity. This is evident in the built-in obsolescence of electronic products like Apple iPhones. Once discarded, such devices release extremely hazardous toxins, often around processing sites in the global South far from their original points of consumption (Lepawsky and McNabb 2010). Waste is also displaced onto fixed capital, appearing as the depreciation or "wearing-out" of machinery, buildings, infrastructure, and so forth during the production process (Marx 1993:710).

Such displacement might be considered a kind of waste switching. By this I mean something like the ghostly underbelly of what Harvey $(1989,2006)$ calls "switching crises", wherein capital flows are shifted from one place to another, or from one circuit to another, opening up new opportunities for productive investments. Taking place in the background, waste switching is what "cleans up" these circuits and allows capital to move freely without becoming mired in the pools of detritus it has left in its path. Starting from the site of production, the living waste of unpaid labour is switched into circulating commodities and fixed capital, where it becomes what Marx (1990:302) calls dead labour or "past labour in its objectified and lifeless form". In Harvey's (2006:236) terms, waste moves from the primary to the secondary circuit of capital, which is essentially the built environment (fixed capital plus a consumption fund made up of commodities that aid in the consumption process). While this switch frees up surplus value in production, it acts as an anti-investment on the secondary circuit, devaluing the built environment and its surroundings through the release of pent-up toxicity, closing off landscapes to potential input-channels of capital. Meanwhile, obsolescence 
and anti-value are foisted onto those living in or near areas of toxic decay in the form of ill-health. Life itself is transformed on a biological level, situating certain bodies - especially the racialised and gendered poor-as "disposable" parts of the commodity that is the built environment (cf. Sparke 2017; Wright 2006). Here anti-value appears as the "phantasmagoria" Marx (1990:165) ascribes to capitalist society, by which dead things come to wield power over the living and are "endowed with a life of their own". As this phantasmagoric spell unfolds over time, entire landscapes are transformed into unreal toxi-cities of dead labour-where toxins reign.

But the unfolding is important: waste switching is also a temporal displacement of toxicity into the future (and into future disease). Anti-investments return at a later date, appearing within different historical configurations of society, technology, and economic imperative. Because of the delay, waste becomes a "new" problem to be solved and can thus create opportunities for productive investment, especially in the areas of science, public health, and risk management. This is seen today in the rise of pharmaceutical and biotechnology industries as well as the emergence of "resilient" urban development-all of which produce commodities for dealing with rising levels of environmental risk (Wakefield and Braun 2014) but which also impose new risks on other people and places in the process (Sparke 2017). Environmental goods and services should be viewed along similar lines, as an industry seeking to cash in on anti-investments, re-collecting the waste of prior production and repositioning it as the basis for new forms of surplus extraction. Anti-value is thus "switched back" into capital's primary circuit, spurring urban growth in ways that weld creative cities to toxi-cities.

The notion of waste switch-back helps to better flesh out the consequences of Marx's phantasmagoria for environmental-service work. For Marx, what's left behind in the wake of accumulation, in its graves, is not truly dead. However hazardous, dead labour is a commodity. It remains fossilised with the "scientific power" and "social powers" of its production process, these having been "transposed ... into the dead productive force" (Marx 1993:715). To be valorised, the dead must be brought back to the surface. As Kirsch and Mitchell (2004:698) put it, "only living labor can bring the dead labor of the past ... to life". It is the environmental industry, among others, that conjures up ("switches back") these ghosts, deferring their death, ensuring that they continue to haunt the present and infuse it with value. These ghosts turn out to be those of the value-form itself, the "phantom-like objectivity" (Marx 1990:128) that "disappears" within the commodity and that is critically revealed as an expression of a social relationship, that of the capitalist class relation. Placed back within the primary circuit of production, the concrete labour of the past, its ecological consequences, is once again transformed into ghostly abstract labour, congealed within a new commodity (now a service) to be sold at a profit.

This is not a complete reversal, however. The revalorisation of waste demands quite different patterns of capital allocation than occurred under earlier accumulation regimes. What's required in particular are new levels of investment in the tertiary circuit of capital, in which Harvey (1989:65-66) includes science and technology development and other social expenditures related to labour 
reproduction. This is clearly apparent in the EGS sector, where large amounts of skilled and "knowledge-based" labour, along with advanced technical equipment, are generally needed to squeeze value out of waste returns. Especially in cities, the EGS sector also relies on heavy investments in the secondary circuit. Urban redevelopment projects and other cleanup activities related to the built environment, as shown below, generate demand for environmental assessment, remediation, and monitoring. So while it is true that EGS re-collects and reactivates the profit potential of earlier cycles of production, it is also bound up with an economic restructuring in which capital is more widely dispersed among its three circuits. Following Harvey's work, this "spreading out" of capital has particular consequences for urban struggles, which I return to in the conclusion.

\section{Environmental Fix}

We are now ready to tell another story about the rise of EGS. Given the profitmaking potential of waste switching, it should no longer appear solely as a matter of policy and public awareness that the industry took off in the US during the 1970 s and 1980s at the national level. This was amid years of global and national economic recession, which saw declines in the annual growth rates of US GDP, particularly from 1974-1975 and 1980-1982 (Amadeo 2017). In complete contrast, the EGS sector grew at an annual average between $9 \%$ and $11 \%$ during this time, reaching as high as 15\% (Berg and Ferrier 1998:7-8). On the urban scale, the EGS sector became particularly important in the 1980s and 1990s with the rise of the remediation services, as discussed above. In Rust Belt cities, the growing environmental industry helped make up for, and was likely spurred on in part by, losses in large-scale manufacturing jobs during these decades (cf. Holifield and Zupan 2014). Geographer John Hathaway (2012) has shown how this was the case in Pittsburgh, whose decimated steel industry has been partially mitigated by a growing environmental sector. To the north of the US, in Ontario, there was a push in the early 1990s to reopen closed industrial plants and repurpose them to produce environmentally friendly goods. The goal of the group running the campaign, the Green Work Alliance, was to "transform the rust belt to a green belt" (Keil 1994:7). Similar tendencies can be seen in US cities like Baltimore, St Louis, and Cincinnati, all of which have experienced significant growth in the EGS sector. Ironically perhaps, much of the environmental work performed in these locations has been made possible by the very industrial processes it has sought to replace, as cleanup efforts often deal with old manufacturing pollutants. The past seems to linger.

And yet cities have tried to move on. The rise of EGS must be viewed as part of a larger economic restructuring that has occurred over the last three decades. This transformation has been driven in part by urban policies that, as advocated by the OECD (1998:25-26), promote the growth of EGS and other "flexible", "technology-based" industries to "replace declining ones" and "stimulat[e] employment". These new industries belong to what the OECD (1998:15) calls the "knowledge-based economy" (see also Mitchell and MacFarlane 2018). Within this economy, a sector like EGS is thought to "create and diffuse new goods and 
services and thereby help instil a culture of innovation" and "encourage investments in skills" (OECD 1998:25). In practice, such restructuring has produced a high number of service-sector jobs in the Rust Belt (Hobor 2013) and elsewhere (OECD 1998:51). While many of these are low-paying and precarious, the EGS sector generally employs a greater share of high-skilled and creative workers than other industries, including many engineers, scientists, and business professionals (OECD 1999b:124). This requires serious investments in science and technology (Harvey's tertiary sector). And while services like environmental remediation are almost always non-basic economic activities that do not, in themselves, bring new money into a region, they are often key components of larger redevelopment projects that aim to attract new industries and capital flows.

As an important part of urban revitalisation, the EGS industry demonstrates that environmental catastrophe may simultaneously pose a threat to and boon for continued accumulation (cf. Cohen and Bakker 2014). On the one hand, the buildup of toxi-cities has led to the widespread depletion of labour power, food, energy, and raw materials (Moore 2015:17), in addtion to creating the impetus for regulations and social movements that have seriously dampened industry's ability to expand and provide spatial fix (Futrell 2000). And yet, over the last decade geographers have shown how environmental externalities can be transformed into a source of profit. Building off Harvey's concept of spatial fix, the set of strategies for accomplishing this is referred to variously as an "environmental fix" (Castree 2008), "ecological fix" (Bakker 2009; Castree and Christophers 2015), "socioecological fix" (Ekers and Prudham 2015; Guthman 2015; McCarthy 2015), or "eco-scalar fix" (Cohen and Bakker 2014). The EGS sector demonstrates how this fix operates on an urban scale - but also in reference to past cycles of production.

As fixes, environmental services are conceived, across the literature, as operating under a neoliberal logic, one that extends market rationalities to environmental governance while incorporating aspects of the non-human into the circuits of capital (see, e.g., McCarthy 2015). The focus on neoliberalism, however, periodises environmental services in a way that obscures how many of the pollutants and hazards addressed by them are leftovers of an earlier (i.e. non-neoliberal) regime of accumulation. While the EGS industry has provided an urban environmental fix since the 1980s, it has often done so by cleaning up a much older past. In other words, what is missing in the analysis of environmental fix is phantasmagoria - the notion that past hazards continue to impinge on value in the present. In addition to producing a demand for "future infrastructure financing" (Castree and Christophers 2015) polluting practices have, as argued above, left behind a trail of dead labour, which certain environmental services are able to recuperate and switch back into the urban market. Unlike neoliberal financial instruments projecting crisis into the future, the EGS industry re-collects the past, breathing new life into the dead, drawing out capitalism's destruction.

\section{Brownfields, Revitalisation, Creative Cities}

Toxic legacies plague the landscapes of many US cities today. As industrial waste accumulated over time and space, contaminated soils began to pose systemic 
risks and shaped urban growth patterns. In particular, they created "new and vexing problems for urban residents and policy makers" while altering "rent-seeking opportunities for manufacturers, developers" and others (Elliott and Frickel 2015:1744). In Harvey's terms, waste clogged up the second circuit of capital, curbing potential investments in the built environment. Much of this clogging has occurred on what are known as brownfield sites. Brownfields are idle, derelict, or "underused" parcels of land with real or potential environmental contamination. They are often located at old industrial or commercial facilities, which have been cheaper to abandon altogether than to cleanup (Gorman 2003). In the mid-1990s, brownfields were considered such a significant problem that the US Conference of Mayors declared them an emergency situation for cities (Bjelland 2004). Pollutants, contaminants, and hazardous substances found at such sites can pose serious threats to environmental and human health. Those at greatest risk of exposure tend to be racialised groups and the poor (Taylor 2014). These health effects are typically filtered through a neoliberal discourse that sees brownfields as an economic blight on the area. As underdeveloped land, brownfields are literally deemed "wasted" opportunities if left alone. As New York City's government website puts it, "[b]rownfields result in lost opportunities to create small businesses, new jobs, affordable housing, and healthy open space in areas where these opportunities are needed most" (NYC.gov 2017). Here poverty, personal health, and the body itself are reimaged as commodities, awaiting remedy by market forces.

A major driver in the commodification of urban pollution, the US Environmental Protection Agency's (EPA) Brownfields Program was designed to give financial and technical support to states, communities, and stakeholders to redevelop and "sustainably reuse" brownfield sites (EPA 2017a). Since its inception in 1995, most recipients have considered the program successful in "stimulating entrepreneurs to remediate and redevelop sites and, sometimes, surrounding neighborhoods" (Greenberg and Issa 2005:83). What is evident in this "success" is how brownfields work has tied environmental cleanup to local and national economic imperatives. This is not to ignore the environmental justice effects of the EPA brownfields program, which has explicitly targeted cities with large minority and low-income populations (Solitare and Greenberg 2002). However, more recent empirical evidence suggests major failures, especially since the early 2000s, in the delivery of this justice (see Dull and Wernstedt 2010). Part of this failure may stem from the economic rationale built into the program. According to the EPA, "[c] leaning up and reinvesting in [brownfields] properties increases local tax bases, facilitates job growth, utilises existing infrastructure, takes development pressures off of undeveloped, open land, and both improves and protects the environment" (2017a). It is through these kinds of environmental services that the polluting practices of an industrial past are recycled and switched back into the accumulation process. At the same time, these pasts are paved over by the focus on specific waste streams, which ignores more general histories of accumulation (Elliott and Frickel 2013) as well as those of environmental injustice.

As former industrial and commercial sites, brownfields are unsurprisingly most prevalent in Rust Belt cities in the Northeast and Upper Midwest where there 
have been significant losses in industrial employment since the 1970s (Simons 1998). Baltimore, for instance, has over 2500 acres of EPA-designated brownfield properties (BDC 2010a). In 2002, this landscape included an estimated 1000 abandoned and "underused" industrial sites that were potentially contaminated by hazardous wastes left over from former manufacturing activities (Litt and Burke 2002). Emphasising histories of industrial disinvestment in such areas, scholars have pointed to the connections, both social and geographic, between brownfields and poverty rates. For example, in her recent study of brownfield sites in Western Pennsylvania, legal scholar Krista Yacovone (2011:203) writes that:

[i]mpoverished and minority populations around brownfield sites experience conditions like those around the steel mills - an economy in decline, decaying infrastructure, lower property values, detrimental health effects, and increased drug use and crime rates.

There is an odd temporality in Yacovone's assessment. Although brownfield sites are strictly postindustrial, either derelict or abandoned, their social effects are said to recall a distant industrial past. With its economic focus, brownfields work in the Rust Belt does not really address this past but conceals it, along with its uneven social relations, within a green future. Waste is switched out of the built environment to become the groundwork for new forms of "sustainable" growth. As Holifield and Zupan (2014:311) note, "brownfields have become key components of recent initiatives to regenerate cities in accordance with principles of sustainable development and environmental justice". This redevelopment is often intended, in Rust Belt cities, to create jobs and attract new industries and capital flows (De Sousa 2014).

Baltimore was at the forefront of the EPA's brownfields program when it launched in 1995 (English 2004). This began with two landmark projects in the late 1990s. The first was the successful 1996 cleanup of 33 acres of the Highland Marine Terminal next to the Canton neighbourhood. The Baltimore Sun described the site as "one of those dark, creepy, forgotten urban corners that seen from a highway or airplane seemed to symbolize the decay of American industry" (Bowie 1996). Cleanup efforts transformed this dilapidated property into cheap warehouse space for port-related businesses. One of these businesses is the Terminal Corporation, which provides logistics, warehousing, and transportation services throughout the Mid-Atlantic Region, opening Baltimore to outside supply chains and commodity flows. Brownfields redevelopment shows how this economic growth, and the flexibilisation of space it implied, is directly connected to gentrification occurring in Baltimore. Just north of the marine terminal is the former American Can Company, the site of the city's second major brownfields project, which took place in 1997 . The reclamation of this manufacturing facility played an integral role in Canton's gentrification, which had already been in motion (see Merrifield 1993).

Baltimore's investment in brownfields initiatives continued throughout the late 1990s. In 1997, the city began participating in a pilot program under the EPA's Brownfield Cleanup Revolving Loan Fund. In the same year, Maryland's 
Brownfields Revitalization Incentive Program (BRIP) was established as part of the state's Smart Growth policy (Cohen 2002). BRIP incentivised environmental cleanup, providing grants, loans, and property tax credits for reclamation efforts. Through these governmental programs, among others, over 40 brownfields projects have been completed in Baltimore (BDC 2010b). These have added or retained an estimated 7000 jobs and have attracted more than $\$ 500$ million in new investment (BDC 2016).

Today, brownfields remediation plays a major role in the redevelopment of Baltimore's Port Covington. Lying south of the Inner Harbor, Port Covington was once the site of an important railroad terminal and is now mostly industrial waterfront. In 2016, real-estate firm Sagamore Development announced its plans to redevelop the 235-acre area. Sagamore, which is owned by billionaire Under Armour CEO Kevin Plank, must first find a way to clean up the area (Sherman 2016). As stressed in the project's draft Master Plan, the redevelopment of Port Covington "begins with thorough environmental assessments and remedial planning" (Baltimore City 2016). Once cleanup is complete, the redevelopment of Port Covington will include housing, offices, restaurants, waterfront parks, and a new global headquarters for Under Armour. While many in Baltimore argue that the redevelopment of Port Covington will further exacerbate the city's already extreme economic and racial disparities, developers and city officials claim it will bring in thousands of jobs.

With Port Covington, Baltimore enters a market of entrepreneurial cities in competition over a so-called "creative class" (Florida 2005) of high-skilled professionals, whose occupations focus on problem solving, knowledge work, and innovation. The EGS industry not only constitutes a growing segment of this socalled class but has also helped-through remediation work - to produce the clean, vibrant, and eco-friendly landscapes with which cities hope to attract additional creative workers, industries, and investments in all three of circuits of capital. This is evident in other urban regions like Milwaukee and Pittsburgh, whose postindustrial revitalisation has been premised on the cleanup and greening of urban space. ${ }^{3}$ One example of this is Milwaukee's redevelopment of the Menomonee Valley. Beginning in the 1990s, the project transformed what was once a 1400 -acre brownfield district into a "vibrant employment center" in the heart of the city (De Sousa 2011:46). As Holifield and Zupan (2014:315) describe it, the project:

emphasized industrial and mixed-use development, designed to create jobs while enhancing the area's appearance through the creation of green space. It would restore the Valley's manufacturing identity, but this time in a more "sustainable" form

Through brownfields work, Milwaukee's past was reimagined and reconstructed in a friendlier aesthetic. The project succeeded in this regard, says geographer Christopher De Sousa (2011:46), and has established the city as "a leader in sustainable urban economic development". This sustainable landscape has, in turn, helped rebrand Milwaukee as an innovative city, replacing images of declining industry with those of lively culture, environment, and consumption 
(Zimmerman 2008). Creative professionals are welcomed with open arms (Holifield and Zupan 2014).

A similar makeover has occurred in Pittsburgh, where over 450 acres of land have been reclaimed through brownfields initiatives (CEEP 2014). Some consider this redevelopment as instrumental to Pittsburgh's "attractive post-industrial success", helping stimulate the local economy and raise property values by millions of dollars (Robinson 2012). Since the mid-1980s, in fact, many residents have seen brownfields revitalisation as a means of catering to the creative class (Dieterich-Ward 2016). The growth of environmental services more generally has created at least 6000 new jobs in the region as of 2012 (Hathaway 2012). These markets provide a sop for some of the surplus labour cast off from the older manufacturing industries, especially in the areas of waste management, water treatment, and sustainable infrastructure development, along with other engineering-focused tasks. The steel industry in Pittsburgh, for instance, spawned an engineering sector, much of which shifted into environmental work when steel declined. For some, there is a sense that the greening of Pittsburgh's economy helps us "forget Pittsburgh's plights of the past" (Greenstein 2012). The city's steel-industry days seem long behind it.

But such economies do not simply disappear in China or India or somewhere offshore. Brownfield sites show how past manufacturing cycles, now as phantasmagoric ruins, continue to play a noxious but valorising role in the present. There is an interesting dialectic at play here, one that Mark Bjelland (2004:631) begins to point out in the context of brownfield sites in Minneapolis-St Paul, between "urban industrial investment and disinvestment". Decades ago, capital inputs in cities like Baltimore, Milwaukee, and Pittsburgh sustained destructive practices that contaminated environments. These environments did not become commodities in themselves until capital was disinvested from the urban core and derelict landscapes began to pose an economic problem. Through cleanup activities, previous investments return with a vengeance. They are, as waste, switched back into the circuits of production. Over time, long-departed industries reappear on the market - now in the ghostly green form of environmental services.

Whether in the Rust Belt or elsewhere, waste switch-back can conceal the private sector under the façade of public issues. Environmental cleanup is often framed - especially in the media and popular culture - as an issue of federal, state, and municipal governance. Indeed, much of the EGS industry's revenue is derived from the public sector, from agencies like the EPA and the US Army Corps of Engineers along with more local entities. Such funds come largely out of taxe imposed and paid at multiple levels. It would thus seem that EGS work falls under the purview of electoral politics, with voters and public officials deciding where and how budgets for cleanup become allocated. And yet the majority of EGS revenue does not in fact come from the government. Most $(51 \%)$ comes from the private sector, and this ratio has been growing over the past couple of decades (Ferrier 2016). This is even more pronounced within urban revitalisation, although it does not always appear so in states where funding comes primarily from taxincrement financing - which blurs the boundaries between public and private backing (see Bjelland and Noyes 2017; Hula and Bromley-Trujillo 2010). Typically 
though, public contracts for environmental cleanup are granted only at government-owned sites or at "orphaned" sites where responsible parties have been impossible to identify. In brownfields work, EGS companies are paid chiefly by property owners, investors, developers, as well as the older manufacturers who have been held legally liable. But when these projects are championed by policymakers and city officials as the key to smart and sustainable growth, private interests begin to appear in line with the public good. While EGS firms play a role in this eco-masquerade, they also show how creative cities are built on toxic foundations.

\section{Creative Toxi-city}

On the surface, the growth and economic vitality of the environmental industry seems to support Richard Florida's (2005) "creative class" thesis, in which postindustrial urban growth hinges on a highly skilled sector of employees in the areas of science, engineering, education, and computer programming, as well as media, arts, and design. The majority of environmental-services labour falls within this demographic. While small-size environmental firms tend to specialise in one or two areas of expertise (such as hydrology or radiological waste), mid-size firms take advantage of economies of scope in order to cobble together unique project teams for addressing the often-complex nature of environmental cleanup. In this they employ a diverse array of knowledge workers, from civil engineers, hydrologists, and chemists to biologists, archaeologists, UXO supervisors, and GIS technicians. With a total of 1852 EPA Superfund sites (EPA 2017b), around 25 billion pounds of toxic chemicals in production-related waste managed each year (EPA 2014), and nearly half of its rivers and streams in poor biological condition (EPA 2016), the US environment seems to have plenty of employment potential for these labour sectors - plenty of waste to switch back.

It is tempting, then, to see environmental services as conservationists of capitalism, helping cities like Baltimore and Pittsburgh back on their feet and, maybe, getting the global economy back to pre-recession rates of GDP growth. In fact, due to the dogged rise of the environmental-services sector over the last 50 years, many within the industry today consider it to be recession immune. During the last recession, this resiliency appeared to hold true. While the US GDP growth rate between 2009 and 2010 was close to zero, the environmental industry grew at $2.4 \%$ in that period (EBI 2014). In 2015, annual growth in the US environmental industry rose to $3.5 \%$ (while US GDP grew by $2.6 \%$ ), yielding $\$ 363$ billion in total revenues ( $2.8 \%$ of US GDP). The company that compiled these numbers forecasts an annual average growth of 3-4\% in 2017-2019 (EBJ 2016).

But it would be a mistake to consider the environmental-services industry, or the service sector more generally, as a sufficient replacement for manufacturing or an environmental fix for local and global economies. There are three reasons for this. First, the remediation of industrial and military sites remains a relatively small business compared to older sectors of production. The 7000 jobs sustained by brownfields cleanups in Baltimore barely make a dent in the 100,000 manufacturing jobs lost between 1950 and 2000 (Boone et al. 2014). Pittsburgh presents an 
even more extreme case. The EGS industry there has generated 6000 jobs, a paltry number compared to the 127,500 manufacturing positions razed from 1979 to 1987 (Duryea 2014).

Second, while the EGS sector as a whole is growing, there have been signs of a slowdown for some time. This has occurred mostly in OECD countries where overcapacity has reduced market expansion (OECD 2005). For the US EGS industry, growth began to taper off around 1990 and has wavered between $1 \%$ and 6\% ever since. Hathaway (2012:S111) explains this slowdown as follows:

The production of Superfund sites fell off, asbestos was no longer used, and most new industrial facilities incorporated increased material efficiency and pollution prevention. In just twenty years of existence, much of the environmental industry showed signs of maturation such as decelerating growth, heightened competition, growing sophistication among its clients, greater emphasis on marketing, and consolidation of market share by larger players.

This decline has been neither constant nor even across the US market. Some metropolitan areas like Pittsburgh have experienced it less than others. Yet there has been a secular tendency for revenue growth to decline. While total industry revenues swelled by $268 \%$ between 1980 and 1990, this rate dropped to $40 \%$ from 1990 to 2008 (Hathaway 2012). This was likely due in part to a decrease in the introduction of new regulations, high levels of compliance with existing regulations, and softened enforcement in the 1990s. It was also bound up with the decline of venture-capital investments in the industry during that decade, which fell from $\$ 200$ million in 1991 to $\$ 20$ million in 1996 (Berg and Ferrier 1998).

The final reason for EGS's insufficiency is a temporal one. In the EGS industry, capital accumulates ex situ. One way or another, the revenues of environmentalservice companies are derived from the refuse of past production, consumption, and circulation. In this sense, environmental services produce very little that is new, at least in terms of surplus value. They are conservationists in the true sense of the word: they conserve the past, rendering it profitable once again. But such recycling seems to be one of diminishing returns, as the past is cleaned up and drained of profit potential.

Meanwhile, this past is conserved in more ways than the economic. Many recent studies demonstrate how environmental services, particularly those aimed at revitalising the urban core, work to preserve, and often exacerbate social mediations of race, class, and gender. Such work contributes to a growing critical environmental justice scholarship (see Benz 2017; Holifield et al. 2009). Much has been written, for instance, on how brownfield redevelopment in cities benefits an elite class (Lees 2003) while negatively impacting already vulnerable populations (Pearsall 2010) and displacing the poor and racialised (Bryson 2012; Essoka 2010). Brownfields programs, along with urban sustainability projects more generally, often go hand in hand with what has been called "green gentrification" (Gould and Lewis 2017) or "environmental gentrification" (Banzhaf and McCormick 2012). This is the process by which green initiatives prepare neighbourhoods for gentrification. As one example, Gould and Lewis (2017) have shown how environmental services and sustainable development in Brooklyn have 
helped fuel rising property costs and the displacement of low-income and minority residents. Something similar has happened in Pittsburgh over the past few years, where greening policies in neighbourhoods like Lawrenceville have skyrocketed housing prices, opened the residential market to outside corporate investment, and forced lower-income individuals out. Sidney Fussell (2017) points out a deep spatial irony in this:

... in an industrial city like Pittsburgh, which the American Lung Association ranked among the nation's worst in air quality, neighborhoods making strides in air or water quality are pushing low income people out of their own neighborhoods and nearer to highways crossing the city, where diesel trucks spew black carbon and near industrial plants where housing is cheapest.

In Pittsburgh and elsewhere, the creative city-its shiny-green aesthetic-is built in part on the landfill of more destructive forms of urbanisation. These practices constitute an urban toxicity or toxi-city, one that is embodied in the unfolding of life and death in enclaves of precarity within the city itself or, as is the case with the global waste trade, in distant parts of the world. Tracing the geographic flows and socioeconomic effects of the global environmental industry provides one way of recognising and situating these toxi-cities in relation to more apparent processes of urbanisation. In particular, the geography of environmental services helps locate within city space what Matthew Sparke (2017:287) has called "biological sub-citizenship", where ill-health "embodies changing conditions of political-economic subordination". This paper suggests that any study of health and the city must attend not just to geographies of the present but also to geographies of the past, to how these are cleaned up, reappropriated, and redistributed today in the construction of new urban fabrics. More work needs to be done here, to map out the distribution of global toxi-cities and to understand how urbanisation manufactures and re-collects its material memories.

\section{Conclusion: Insurgent Re-collection}

... even the dead will not be safe from the enemy if he wins. (Benjamin 1968:255)

Today, the US environmental industry is facing what Walter Benjamin called a "moment of danger". With the likes of climate-sceptic Scott Pruitt at the helm of the EPA, the Trump administration has begun unravelling decades-old environmental protections. This danger extends beyond the present-into the soils of history. As Lindsey Dillon has noted, the Trump regime poses a threat to the archive of climate change itself. Already it has "overhauled important environmental web pages, removed documents related to climate change, and altered the ways environmental webpages refer to climate change in a way that obscures or at least significantly downplays the issue" (quoted in McNulty 2018). What is at stake is not just the erasure of prior acts of environmental destruction, but also the future experience and embodiment of risk within certain places and bodies, at sites where the toxicity of history may be buried and forgotten, displaced from today's toxi-cities. As in Benjamin's time, the past—and thus the future —is never safe from the enemy. 
And yet, also as in Benjamin's time, it is a mistake to look on the Trump regime's action with amazement, as if "the things we are experiencing are 'still' possible in the ... [21 $\left.{ }^{\text {st }}\right]$ century" (Benjamin 1968:257). Moments of danger are also opportunities for struggle. They reopen the past: flashing up forgotten shards of "waste" that might be seized in the present as points of orientation. This is especially true in urban spaces where, as Allan Pred (2004:202) underlined in his last writings, "the past is not dead-but ... rearticulated with new circumstances and social formations". Here, waste can be "put into practice".

The Environmental Data and Governance Initiative (EDGI) is a step in this direction. EDGl, whose steering committee is chaired by Dillon, is an international network of over 85 archivists, academics, lawyers, and others working to promote and monitor public environmental data. What might be taken from EDGI is not its overall mission, which seems to be one of shoring up state regulation, warding off "potential threats to federal environmental and energy policy". As Wakefield and Braun (2014:10) argue, a radical environmental politics today "does not reinstantiate government" but creates new spaces of being beyond those produced by governmental technologies. But there is something about EDGI's approach to time that challenges the ontological-focus of Wakefield and Braun's (2014:9) political conclusions, which are about how best "to dwell in the Anthropocene, to experiment with its indeterminate and often terrifying futures". This is a politics shared by Jason Moore (2016:114) whose concept of "liberation" entails the creative capacity "to forge a different ontology of nature, humanity, and justice". The question EDGl throws up is this: What if the horizon of struggle is not the future so much as the past? What if the materials of revolution are already at our feet, so to speak, in the waste and data left behind?

Rather than "imagine lines of flight-new territories" (Wakefield and Braun 2014:10) or dream up future "non-capitalist agronomies" (Moore 2015:287), there is another politics that refuses to wait, that treats the present as already layered with multiple temporalities and radical possibilities, which are dug up and switched back at certain moments (see Tomba 2013). Of course, the practice of digging into time is not radical in itself. Capital accumulation also relies on temporal strategies, deferring certain futures and revitalising certain pasts. This paper has pointed to the EGS industry as an increasingly relevant example of such a strategy, one that places special emphasis on the re-collection of dead labour. And yet, as the past is brought to the surface-or threatened with erasure altogether-another kind of re-collection becomes not only thinkable but critical.

Different negotiations of time and space come with different consequences for urban struggle (Harvey 1989). As mentioned above, the rise of the EGS industry is part and parcel of a tendency to "spread out" capital among Harvey's three circuits. This has the overall effect of shifting a degree of pressure off the primary circuit of capitalist production, concealing (while further entrenching) some of its contradictions by displacing them onto other spheres of social activity. These spheres include those related to the secondary and tertiary circuits of capital, namely the built environment and social reproduction. The result of this 
spreading out is that struggles around wage labour are ever more imbricated with, and inseparable from, struggles over the right to the city (built environment) and the right to produce life otherwise (social reproduction). It is no longer possible, if it ever was, to speak of abolishing class divisions without confronting the racialised and gendered character of life in the city and its growing "hinterland" (Neel 2018). Such constellations of insurgency remain bound together by waste, by a fidelity to what and to who has been cast aside. Rather than play the shell game of waste switching, the goal is to break out of the phantasmagoric circuitry of capital altogether-to re-collect "excess" in ways that refuse to reinsert it into the same processes from which it had been excreted. This re-collection is non-creative in the sense that it does not seek out new ontologies or forms of life quarantined from the toxic grounds of the present-but works to emancipate what is already here.

One sketch of insurgent re-collection can be found in a short text written by Walter Benjamin in 1932, left unpublished during his lifetime. In this fragment, titled "Excavation and Memory", Benjamin (2005:576) describes archaeological work as an allegory for remembrance. Like the EGS industry, the archaeologist digs into the "strata" where "ancient cities lie buried", returning "again and again to the same matter; to scatter it as one scatters earth, to turn it over as one turns over soil". But what separates Benjamin's re-collection from that of EGS is that it does not seek to switch waste back into the circuits of capitalist production. Instead, the forgotten ruins and images excavated by the archaeologist are "severed from all earlier associations". Rather than being remediated, the past is redeemed from the law of value that separates out people and things as "dead" or "waste" in the first place.

With its practice of severing - or demediation - the insurgent re-collection of Benjamin's archaeologist literally widens the historical-geographic scope of the urban. What's produced is an "archaeological report" that is not merely an "inventory of ... findings" but a sharp tool for grasping the landscape beneath its immediate appearance in the present. It "inform[s] us about the strata from which its findings originate" along with "the strata which first had to be broken through". When taken collectively, such re-collection is inseparable from a militant urban politics. It provides a map, not of alternatives in the present (see Moore 2015:288) or beyond the present, but of the present itself in a historically charged form, one that can be seized and transformed. It is around such mineralised grounding points that urban struggles can and do orient themselves today-linking up with one another in a real Rust Belt that stretches urgently across both space and time. Here, rather than capitalist society digging its own grave, we take up the spades ourselves. In the dark loam we excavate a better future, switching waste out of its circuits once and for all.

\section{Acknowledgements}

Many thanks to Ian MacFarlane, Katharyne Mitchell, Phil Neel, Matt Sparke, Max Tomba, and the three anonymous reviewers for all their thoughtful comments and for helping me get this "waste" into better shape. Parts of this paper were presented at the 2018 
American Association of Geographers meeting in New Orleans during a great set of paper sessions organised by Cynthia Morinville and Nicole Van Lier.

\section{Endnotes}

1 In The Communist Manifesto, Marx and Engels argue that the "development of modern industry ... cuts from under the feet the very foundation on which the bourgeoisie produces and appropriates products. What the bourgeoisie therefore produces, above all, are its own grave-diggers" (2012:50).

2 See Inverardi-Ferri (2018) for another recent attempt to situate waste in relation to Harvey's work and the circuits of capital, but one more concerned with issues of informal economy.

3 Postindustrial greening has occurred in cities outside the US as well, such as in Germany's Ruhr Valley (see Wachsmuth and Angelo 2018).

\section{References}

Amadeo K (2017) The strange ups and downs of the U.S. economy since 1929. The Balance 18 October. https://www.thebalance.com/us-gdp-by-year-3305543 (last accessed 22 July 2018)

Bakker K (2009) Neoliberal nature, ecological fixes, and the pitfalls of comparative research. Environment and Planning A 41(8):1781-1787

Baltimore City (2016) "Port Covington Master Plan Draft, 16 June 2016." https://plan ning.baltimorecity.gov/sites/default/files/PORT\%20COVINGTON\%20MASTER\%20PLAN\% 20061616\%20v11\%206.22.16.pdf (last accessed 31 July 2018)

Banzhaf H S and McCormick E (2012) Moving beyond cleanup: Identifying the crucibles of environmental gentrification. In H S Banzhaf (ed) The Political Economy of Environmental Justice (pp 23-51). Stanford: Stanford University Press

BDC (2010a) "Baltimore Brownfields Initiative." Baltimore Development Corporation. http://baltimoredevelopment.com/wp-content/uploads/2014/07/bdc_brownfields_marke tingsheet-.pdf (last accessed 31 July 2018)

BDC (2010b) "Maryland and Baltimore Brownfields Incentives." Baltimore Development Corporation. http://baltimoredevelopment.com/wp-content/uploads/2014/07/bdc_brown fieldsincentives_marketingsheet-.pdf (last accessed 31 July 2018)

BDC (2016) "Brownfields Tax Credit." Baltimore Development Corporation. http://balti moredevelopment.com/incentives/brownfield/ (last accessed 31 July 2018)

Benjamin W (1968[1940]) Theses on the philosophy of history. In H Arendt (ed) Illuminations (pp 253-264). New York: Schocken Books

Benjamin W (2005) Walter Benjamin: Selected Writings-Volume 2, Part 2, 1931-1934 (eds M W Jennings, $\mathrm{H}$ Eiland and G Smith). Cambridge: Harvard University Press

Benz T A (2017) Toxic cities: Neoliberalism and environmental racism in Flint and Detroit, Michigan. Critical Sociology https://doi.org/10.1177/0896920517708339

Berg D R and Ferrier G (1998) The U.S. Environmental Industry. Washington, DC: US Department of Commerce, Office of Technology Policy

Bjelland M D (2004) Brownfield sites in Minneapolis-St. Paul: The interwoven geographies of industrial disinvestment and environmental contamination. Urban Geography 25 (7):631-657

Bjelland M D and Noyes I (2017) Urban revitalization in a neoliberal key: Brownfield redevelopment in Michigan. In N Wise and J Clark (eds) Urban Transformations: Geographies of Renewal and Creative Change (pp 43-61). New York: Routledge

Boone C G, Fragkias M, Buckley G L and Grove J M (2014) A long view of polluting industry and environmental justice in Baltimore. Cities 36:41-49

Bowie L (1996) Cleanup of terminal opens possibilities. The Baltimore Sun 5 November

Boyd J and Banzhaf S (2007) What are ecosystem services? The need for standardized environmental accounting units. Ecological Economics 63(2):616-626 
Brenner N and Schmid C (2017) Elements for a new epistemology of the urban. In S Hall and R Burdett (eds) The Sage Handbook of the $21^{\text {st }}$ Century City (pp 47-68). Los Angeles: Sage

Bryson J (2012) Brownfields gentrification: Redevelopment planning and environmental justice in Spokane, Washington. Environmental Justice 5(1):26-31

Castree N (2008) Neoliberalising nature: The logics of deregulation and reregulation. Environment and Planning A 40(1):131-152

Castree N and Christophers B (2015) Banking spatially on the future: Capital switching, infrastructure, and the ecological fix. Annals of the Association of American Geographers 105(2):378-386

CEEP (2014) "Brownfields: From Redevelopment to Revitalization." Center for Energy and Environmental Policy, University of Delaware. https://dspace.udel.edu/bitstream/handle/ 19716/13108/2014_ej_Brownfields_from_Redevelopment_to_Revitalization.pdf?seque nce $=1$ \&isAllowed=y (last accessed 31 July 2018)

Cohen A and Bakker K (2014) The eco-scalar fix: Rescaling environmental governance and the politics of ecological boundaries in Alberta, Canada. Environment and Planning D: Society and Space 32(1):128-146

Cohen J R (2002) Maryland's "Smart Growth": Using incentives to combat sprawl. In G D Squires (ed) Urban Sprawl: Causes, Consequences, and Policy Responses (pp 293-324). Washington, DC: The Urban Institute Press

Crutzen P (2002) Geology of mankind. Nature 415(6867):23

De Sousa C (2011) Greening the industrial district: Transforming Milwaukee's Menomonee Valley from a blighted brownfield into a sustainable place to work and play. In M I Slavin (ed) Sustainability in America's Cities: Creating the Green Metropolis (pp 45-67). Washington, DC: Island Press

De Sousa C (2014) The greening of urban post-industrial landscapes: Past practices and emerging trends. Local Environment 19(10):1049-1067

Dieterich-Ward A (2016) Beyond Rust: Metropolitan Pittsburgh and the Fate of Industrial America. Philadelphia: University of Pennsylvania Press

Dillon L (2014) Race, waste, and space: Brownfield redevelopment and environmental justice at the Hunters Point Shipyard. Antipode 46(5):1205-1221

Dull M and Wernstedt K (2010) Land recycling, community revitalization, and distributive politics: An analysis of EPA brownfields program support Policy Studies Journal 38(1):119_ 141

Duryea S (2014) Holding on to steel: Pittsburgh culture in the age of globalization. Globalizations 11(6):767-776

EBI (2014) "EBI Report 725: The U.S. Environmental Consulting \& Engineering Industry." Environmental Business International

EBJ (2015) Environmental consulting and engineering industry review and outlook 20142016. Environmental Business Journal 28(10/11)

EBJ (2016) Environmental industry overview 2016. Environmental Business Journal 29(9/10)

EB] (2017) Global environmental market 2017. Environmental Business Journal 30(5/6)

Ekers M and Prudham S (2015) Towards the socio-ecological fix. Environment and Planning A 47(12):2438-2445

Elliott J and Frickel S (2013) The historical nature of cities: A study of urbanization and hazardous waste accumulation. American Sociological Review 78(4):521-543

Elliott J and Frickel S (2015) Urbanization as socioenvironmental succession: The case of hazardous industrial site accumulation. American Journal of Sociology 120(6):1736-1777

Ellis D and Hadley P (2009) Integrating sustainable principles, practices, and metrics into remediation projects. Remediation Journal 19(3):5-114

English M (2004) A brighter future in brownfields. The Baltimore Sun 26 January

EPA (2014) "TRI National Analysis 2014: Introduction." U.S. Environmental Protection Agency. https://www.epa.gov/sites/production/files/2016-01/documents/tri_na_2014_c omplete_english.pdf (last accessed 31 July 2018)

EPA (2016) "National Rivers and Streams Assessment 2008-2009: A Collaborative Survey (EPA/841/R-16/007)." Office of Water and Office of Research and Development, United 
States Environmental Protection Agency. https://www.epa.gov/sites/production/files/ 2016-03/documents/nrsa_0809_march_2_final.pdf (last accessed 1 August 2018)

EPA (2017a) "Overview of the Brownfields Program." United States Environmental Protection Agency. https://www.epa.gov/brownfields/overview-brownfields-program (last accessed 1 August 2018)

EPA (2017b) "National Priorities List and Superfund Alternative Agreement Sites." United States Environmental Protection Agency. https://www.epa.gov/superfund/search-superf und-sites-where-you-live (last accessed 1 August 2018)

Essoka J (2010) The gentrifying effects of brownfields redevelopment. Western Journal of Black Studies 34(3):299-315

Ferrier G (2016) "2017 Environmental Industry Overview." Paper presented to the $14^{\text {th }}$ Annual Environmental Industry Summit, 9-11 March. http://sameoc.org/FD/2017/ SAME_OC_Post_Ferrier.2017.02FEB.23.pdf (last accessed 1 August 2018)

Fisher B, Turner R and Morling P (2009) Defining and classifying ecosystem services for decision making. Ecological Economics 68(3):643-653

Florida R (2005) Cities and the Creative Class. New York: Routledge

Fussell S (2017) Pittsburgh is going green, but who is getting left behind? Gizmodo 1 September. https://gizmodo.com/pittsburgh-is-going-green-but-who-is-getting-left-be hi-1798531035 (last accessed 1 August 2018)

Futrell R (2000) Politics of space and the political economy of toxic waste. International Journal of Politics, Culture and Society 13(3):447-476

Gidwani V (2008) Capital, Interrupted: Agrarian Development and the Politics of Work in India. Minneapolis: University of Minnesota Press

Gidwani V (2016) Waste/value. In T J Barnes, J Peck and E Sheppard (eds) The Wiley-Blackwell Companion to Economic Geography (pp 275-288). Malden: Wiley

Gidwani V and Reddy R N (2011) The afterlives of "waste": Notes from India for a minor history of capitalist surplus. Antipode 43(5):1625-1658

Gorman H S (2003) Brownfields in historical context. Environmental Practice 5(1):21-24

Gould K A and Lewis T L (2017) Green Gentrification: Urban Sustainability and the Struggle for Environmental Justice. London: Routledge

Greenberg M and Issa L (2005) Measuring the success of the federal government's Brownfields Program. Remediation Journal 15(3):83-94

Greenstein T (2012) Green living in America's "Steel City". Forbes 29 June

Guthman J (2015) Binging and purging: Agrofood capitalism and the body as socioecological fix. Environment and Planning A 47(12):2522-2536

Harvey D (1989) The Urban Experience. Baltimore: Johns Hopkins University Press

Harvey D (2006) The Limits to Capital. London: Verso

Harvey D (2018) Marx, Capital, and the Madness of Economic Reason. Oxford: Oxford University Press

Hathaway J (2012) Geographical dynamics of environmental service firms at metropolitan and national scales in the United States: The case of Pittsburgh, Pennsylvania. Urbani Izziv 23(s2):s107-s116

Hobor G (2013) Surviving the era of deindustrialization: The new economic geography of the urban Rust Belt. Journal of Urban Affairs 35(4):417-434

Holifield R and Zupan S (2014) Keep costumes out, keep trains in: Defining and defending spaces for "good jobs" in a Rust Belt city. Geo/ournal 79(3):309-328

Holifield R, Porter M and Walker G (2009) Spaces of environmental justice: Frameworks for critical engagement. Antipode 41(4):591-612

Hula R C and Bromley-Trujillo R (2010) Cleaning up the mess: Redevelopment of urban brownfields. Economic Development Quarterly 24(3):276-287

Inverardi-Ferri C (2018) The enclosure of "waste land": Rethinking informality and dispossession. Transactions of the Institute of British Geographers 43(2):230-244

Katz C (2011) Accumulation, excess, childhood: Toward a countertopography of risk and waste. Documents d'Anàlisi Geogràfica 57(1):47-60

Keil R (1994) Green Work Alliances: The political economy of social ecology. Studies in Political Economy 44:7-38 
Kirsch S and Mitchell D (2004) The nature of things: Dead labor, nonhuman actors, and the persistence of Marxism. Antipode 36(4):687-705

Kraft M (2000) U.S. environmental policy and politics: From the 1960s to the 1990s. Journal of Policy History 12(1):17-42

Krupar S R (2011) Alien still life: Distilling the toxic logics of the Rocky Flats National Wildlife Refuge. Environment and Planning D: Society and Space 29(2):268-290

Landry C (2008) The Creative City: A Toolkit for Urban Innovators. New York: Earthscan

Lees L (2003) Policy (re)turns: Gentrification research and urban policy-urban policy and gentrification research. Environment and Planning A 35(4):571-574

Lepawsky J and McNabb C (2010) Mapping international flows of electronic waste. The Canadian Geographer/Le Géographe canadien 54(2):177-195

Lindner C and Meissner M (eds) (2016) Global Garbage: Urban Imaginaries of Waste, Excess, and Abandonment. New York: Routledge

Litt J S and Burke T A (2002) Uncovering the historic environmental hazards of urban brownfields. Journal of Urban Health 79(4):464-481

Lounsbury M, Ventresa M and Hirsch P (2003) Social movements, field frames, and industry emergence: A cultural-political perspective on U.S. recycling. Socio-Economic Review 1 (1):71-104

Marx K (1990 [1867]) Capital, Volume 1. London: Penguin

Marx K (1993 [1873]) Grundrisse. London: Penguin

Marx K and Engels F (2012 [1848]) The Communist Manifesto. London: Verso

McCarthy J (2015) A socioecological fix to capitalist crisis and climate change? The possibilities and limits of renewable energy. Environment and Planning A 47(12):2485-2502

McNulty J (2018) Trump environmental watchdog group issues third report. UC Santa Cruz Newscenter 10 January. https://news.ucsc.edu/2018/01/dillon-edgi.html (last accessed 1 August 2018)

Merrifield A (1993) The struggle over place: Redeveloping American Can in Southeast Baltimore. Transactions of the Institute of British Geographers 18(1):102-121

Mitchell K and MacFarlane K (2018) Geographies of lifelong learning and the knowledge economy. In K Mitchell (ed) Making Workers: Radical Geographies of Education (pp 6782). London: Pluto

Moore J (2014) Wasting away: Value, waste, and appropriation in the capitalist world-ecology. World-Ecological Imaginations: Power and Production in the Web of Life 1 April. https://jasonwmoore.wordpress.com/2014/04/01/wasting-away-value-waste-and-appro priation-in-the-capitalist-world-ecology/ (last accessed 1 August 2018)

Moore J (2015) Capitalism in the Web of Life: Ecology and the Accumulation of Capital. London: Verso

Moore J (2016) The rise of cheap nature. In J Moore (ed) Anthropocene or Capitalocene? Nature, History, and the Crisis of Capitalism (pp 78-115). Oakland: PM Press

Neel P (2018) Hinterland: America's New Landscape of Class and Conflict. London: Reaktion

NYC.gov (2017) "Brownfields." New York City Mayor's Office of Sustainability. https:// www1.nyc.gov/site/sustainability/initiatives/brownfields.page

OECD (1998) Technology, Productivity, and Job Creation: Best Policy Practices. Paris: Organisation for Economic Co-operation and Development

OECD (1999a) The Environmental Goods and Services Industry Manual for Data Collection and Analysis: Manual for Data Collection and Analysis. Paris: Organisation for Economic Cooperation and Development

OECD (1999b) Special issue on sustainable development STI Review 25

OECD (2005) Trade that Benefits the Environment and Development Opening Markets for Environmental Goods and Services: Opening Markets for Environmental Goods and Services. Paris: Organisation for Economic Co-operation and Development

Pearsall H (2010) From brown to green? Assessing social vulnerability to environmental gentrification in New York City. Environment and Planning C: Government and Policy 28 (5):872-886

Percival R V, Schroeder C H, Miller A S and Leape J P (2015) Environmental Regulation: Law, Science, and Policy. New York: Wolters Kluwer Law \& Business 
Pred A (2004) The Past Is Not Dead: Facts, Fictions, and Enduring Racial Stereotypes. Minneapolis: University of Minnesota Press

Robinson B (2012) Turning land from brown to green: Pittsburgh's reuse of industrial sites is a story worth telling. Pittsburgh Post-Gazette 13 October

Schoenberger E (2015) Nature, Choice, and Social Power. New York: Routledge

Schoenberger E and Walker R (2017) Beyond exchange and agglomeration: Resource flows and city environments as wellsprings of urban growth. Journal of Economic Geography 17 (5):935-958

Sherman N (2016) 17 things to know about the Port Covington TIF. The Baltimore Sun 29 April. http://www.baltimoresun.com/business/bs-bz-things-to-know-about-port-covington20160429-story.html (last accessed 22 July 2018)

Simons R (1998) How many urban brownfields are out there? An economic base contraction analysis of 31 U.S. cities. Public Works Management and Policy 2(3):267-273

Sinclair-Desgagné B (2008) The environmental goods and services industry. International Review of Environmental and Resource Economics 2(1):69-99

Sine $W$ and Lee B (2009) Tilting at windmills? The environmental movement and the emergence of the U.S. wind energy sector. Administrative Science Quarterly 54(1):123-155

Solitare L and Greenberg M (2002) Is the U.S. Environmental Protection Agency brownfields assessment pilot program environmentally just? Environmental Health Perspectives 110(s2):249-257

Sparke M (2017) Austerity and the embodiment of neoliberalism as ill-health: Towards a theory of biological sub-citizenship. Social Science and Medicine 187:287-295

Sutherson S, Horst J, Schnobrich M, Welty N and McDonough J (2017) Remediation Engineering: Design Concepts. Boca Raton: CRC

Taylor D (2014) Toxic Communities: Environmental Racism, Industrial Pollution, and Residential Mobility. New York: NYU Press

Tomba M (2013) Marx's Temporalities. Leiden: Brill

US International Trade Commission (2013) "Environmental and Related Services." Investigation No. 332-533, USITC Publication 4389

Vikhlyaev A (2004) Environmental goods and services: Defining negotiations or negotiating definitions? In UNCTAD Trade and Environment Review 2003 (pp 33-60). New York: United Nations

Wachsmuth D and Angelo H (2018) Green and gray: New ideologies of nature in urban sustainability policy. Annals of the American Associate of Geographers 108(4):1038-1056

Wakefield S and Braun B (2014) Governing the resilient city. Environment and Planning D: Society and Space 32(1):4-11

Wright M W (2006) Disposable Women and Other Myths of Global Capitalism. New York: Routledge

Yacovone K (2011) Brownfields and the poor: Is cleanup a hazardous waste of time? An analysis of the United States' efforts at remediation and their applicability to Brazil. Fordham International Law Journal 35(1):201-247

Zimmerman J (2008) From brew town to cool town: Neoliberalism and the creative city development strategy in Milwaukee. Cities 25(4):230-242 